\section{J. Graham Watt}

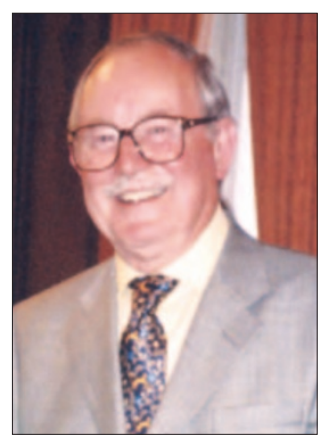

Graham Watt died very suddenly on 2 March 2005. Born on 9 June 1922, his education started and finished in Edinburgh, having spent his school years at Melville College and then qualifying from the Dental School in 1943. He joined the Royal Navy, serving in Australia and Ceylon and was decommissioned in 1947.

General practice then beckoned and took him to Bromley, where he joined the practice of Mr Mackenzie Veale, becoming the principal in 1950 on Mr Veale's retirement. The practice lease expired in 1971 so he oversaw not only the move to new premises but also the conversion of that building to a four-surgery practice. This was a strong NHS-based practice and Graham devoted most of his spare time to NHS organisations and the BDA.

He was a member of the SE London \& Kent Executive Committee before moving on to Bromley LDC from its start in 1974 until his retirement. He was one of the founder members of the Bromley and Beckenham section of the BDA, and served as Secretary and Chairman of not only the Section, but also as Secretary from 1966-71 and President in 1973/4 of the Southern Counties Branch of the BDA. He served on the Representative Board of the BDA for many years, and was made a Life Member for his services. He also found time to be a part-time Board Member of the Dental Estimates Board when Ron Proudler was Chairman in the early days of the first capitation scheme.

\section{Graham devoted most of his spare time to NHS organisations and the BDA.}

He was joined in the practice by his son, Martin, in 1972 and later Martin's wife, Yvonne, in 1982, so it became a family practice in more than the usual sense! Graham retired in 1987 and saw the practice move into the independent sector in 1990, since when it has continued to prosper.

His leisure time was spent on the golf course, being a member of Chislehurst GC for over 40 years, and on several courses in his beloved Scotland, particularly on the island of Arran. It was here back in the late 1930s that he met Pamela, marrying her in 1946. With family now in Toronto, they both enjoyed many holidays there, later having holidays within holidays as retirement meant longer spells there so he was able to explore much of the eastern cities of Canada. Gardening, choral music recitals, the history of Scotland and in particular Edinburgh, also occupied his time after work. In retirement he went back to his roots in two areas; in one he traced his family tree back to the mid-1600s, and secondly his Naval roots with a voluntary post at the Naval Maritime Museum at Greenwich, doing historical research and cataloguing P \& O's vast collection of slides and prints from their past.

Graham is survived by his wife, Pamela, two children, Martin and Louise, two grandchildren and a thriving practice.

M. Watt

\title{
Edgar Sidney Venning
}

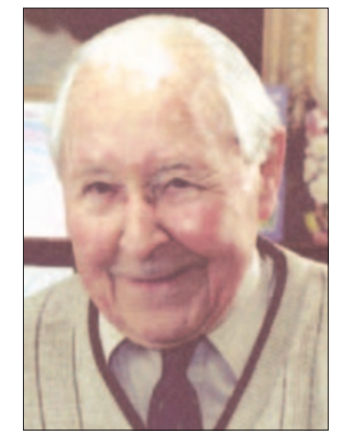

Edgar Venning died peacefully in Howard House Nursing Home, Gerrards Cross on 10 June 2006, a month after his 95th birthday.

Born in Plymouth in 1911, he studied dentistry at Guy's Hospital and qualified in 1934. He was a house surgeon at Guy's, following which he did a threemonth postgraduate course at the Northwestern University, Chicago.

He went into private practice in St John's Wood, London, and whilst there he met his future wife, Jean. When war was declared Edgar joined the RAF, and as a squadron leader he led a squadron of mobile dental units and a mobile laboratory through Europe. He was later mentioned in despatches.

After the war Edgar started a dental practice in Gerrards Cross,

\section{In the RAF he led a squadron of mobile dental units through Europe.}

where he worked until his retirement in 1976. He was always a keen member of the BDA, his father Sydney having been President in 1936. His uncle Lotan was also BDA President in 1959.

He had many interests outside of dentistry, including scouting, amateur dramatics and caravanning.

He leaves his wife Jean (to whom he was married for 66 years) and children Peter, Elizabeth and Catherine, together with six grandchildren.

Peter followed his father into dentistry at Guy's, and is still in dental practice in Shoreham-by-Sea, West Sussex.

P. D. Venning 